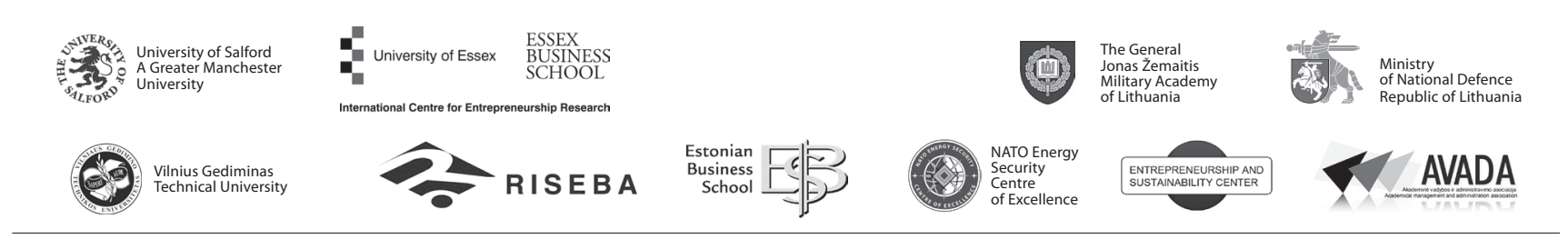

JOURNAL OF SECURITY AND SUSTAINABILITY ISSUES

ISSN 2029-7017 print/ISSN 2029-7025 online

2015 June Volume 4 Number 4

http://dx.doi.org/10.9770/jssi.2015.4.4(5)

\title{
ILLEGAL TRAFFICKING AND UNSUSTAINABLE WASTE MANAGEMENT IN ITALY: EVIDENCE AT THE REGIONAL LEVEL
}

\author{
Anna Rita, Germani ${ }^{1}$ Antonio, Pergolizzi ${ }^{2}$ Filippo, Reganati $^{3}$ \\ ${ }^{1}$ University of Rome 'Sapienza', p.le A. Moro, 5-00185-Rome, Italy \\ ${ }^{2}$ Legambiente, via Salaria, 403 - 00199 - Rome, Italy \\ ${ }^{3}$ University of Rome 'Sapienza', p.le A. Moro, 5-00185-Rome, Italy
}

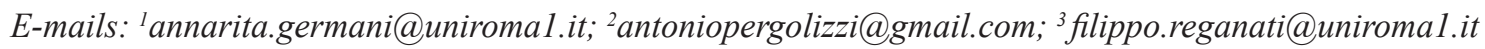

Received 10 February2015; accepted 18 April 2015

\begin{abstract}
The presence of organized crime strongly affects sustainable waste management in Italy. In particular, illegal trafficking of waste has become one of the fastest growing areas of crime and one of the most lucrative industries among organized criminal activities, which has now infiltrated both the Italian urban and hazardous waste management cycle. In this study, we aim to investigate the determinants of the illegal trafficking of waste using waste, economic, and enforcement data in a panel analysis over the period 2002-2013. The topic is particularly relevant, given the high heterogeneity across Italian regions which also relates, and eventually leads, to different environmental performances. Our main findings reveal that, in most Italian regions, enforcement activities do not exert a significant deterrence on criminal behaviors; a negative relationship between enforcement and illegal trafficking of waste can be identified only for very high levels of enforcement efforts. Moreover, we find that the major determinants influencing the rate of illegal trafficking of waste differ between northern-central and southern regions, confirming the existence of a regional dualism. In particular, while in the northern-central area the crime rate is positively related to the level of education and negatively to the adoption of environmentally sound policies, in southern regions the organized activities for illegal trafficking are negatively related to the degree of education attainment and positively to the endowment of waste management plants.
\end{abstract}

Keywords: illegal trafficking, waste, law enforcement, organized crime, waste management, sustainability

Reference to this paper should be made as follows: Germani A.R.; Pergolizzi A.; Reganati F. 2015. Illegal trafficking and unsustainable waste management in Italy: evidence at the regional level, Journal of Security and Sustainability Issues 4(4): 369-389.

DOI: http://dx.doi.org/10.9770/jssi.2015.4.4(5)

JEL Classifications: F12, F23, F61

\section{Introduction}

The illegal trafficking of waste has become one of the fastest growing areas of crime and is one of the most important environmental problems worldwide, attracting the growing interest of unscrupulous brokers as well as criminal networks. As recently highlighted by UNEP and Interpol ${ }^{1}$, environmental crimes can potentially affect a variety of sectors in any society and are often linked with the exploitation of disadvantaged communities, human rights abuses, money laundering and corruption (Zahars, Stivrenieks 2015). The European Union Network for the Implementation and Enforcement of Environmental Law (IMPEL) suggests that as much as $85 \%$ of the non-hazardous waste exported from the EU is shipped illegally or in non-compliance with regulations. Globally, the annual turnover in the illegal trade of environmentally sensitive commodities is estimated at around $\$ 21.33$ billion. In Italy, the Legambiente Report (2014) argued that the economic returns from the illegal

1 UNEP Press release (2013). “UNEP and INTERPOL Assess Impacts of Environmental Crime on Security and Development”. Available online at: http:// www.unep.org/environmentalgovernance/News/PressRelease/tabid/427/language/en-US/Default.aspx?DocumentID=2755\&Arti- cleID=9686\&Lang=en 
trafficking of hazardous waste in 2010 were approximately $€ 3.1$ billion $^{2}$. According to the Italian Financial Police (Guardia di Finanza), economic motivation is one of the most important factors inducing firms to illegally dispose of waste: a European company pays about $€ 60000$ to legally dispose a container full of 15000 tons of hazardous waste, while the same amount of waste can be illegally disposed for only $€ 5000$ in Eastern Europe or Asia. In Italy, in addition to the diffusely high levels of corruption, there is often the problem of a weak or inadequate enforcement system on account of two main reasons: i) the lack of economic resources devoted to crime prevention and control and ii) the strong interaction and collusion between political parties and industrial lobbies that affects the criminal environmental legislation and its effective enforcement. These circumstances have created the prevalence of a system that allows generating private profits while environmental costs are social. The illegal trafficking of waste is an emblematic example of such a system, which is in turn encouraged by a weak degree of social perception, given that eco-crimes are usually defined as "crimes without victims", since the victims are not immediately identifiable.

Following the economics of crime literature (Becker 1968; Ehrlich 1973; Levitt 1999; Polinsky and Shavell 2000; Stańczyk 2011; Lankauskienė, Tvaronavičienè 2012; Šileika, Bekerytė 2013; Račkauskas, Liesionis 2013; Tunčikienè, Drejeris 2015; Giriūnas, Mackevičius 2014; Giriūnienė 2013), it is well known that people will commit a crime if the gain exceeds their (opportunity) costs. In our case, the illegal trafficking of waste arises when higher profits are expected compared to legal options of recycling or disposal, combined with regulatory or enforcement failure. As far as the illegal discarding of waste is concerned, in 2013, the law enforcement authorities in Italy acknowledged 5744 offences, with 6971 people accused, 90 arrests carried out and 2318 seizures (Legambiente 2014). The three regions most affected by the illegal activities were, in order, Campania, Calabria and Apulia: This data confirms the incidence of these phenomena in territories traditionally characterized by the presence of Mafia. Prevalence can also be seen in Lombardy, Latium, Tuscany, Sardinia and, at eighth position, Sicily.

In the Italian legal system, the criminal protection of the environment is almost entirely limited to a series of misdemeanors, which fall outside the Penal Code ${ }^{3}$. As far as the illegal trafficking of waste is concerned, it was firstly introduced in Article 259 of the Environmental Code (D.Lgs. 152/2006) on the "Illegal shipment of waste", which punishes "whoever carries out a shipment of waste constituting illicit traffic according to Article 26 of the Regulation (European Economic Community) 1 February 1993, no. 259 or carries out a shipment of waste listed in the Annex II of the above-mentioned Regulation in violation of article 1, par. 3, a), b), c) and d), of the Regulation itself shall be punished with a fine from $€ 1550$ to $€ 26000$ and with arrest of up to two years. The penalty is increased in case of shipment of dangerous waste".

Amongst the few cases that do include the felony, there is the case of organized activities for the illegal trafficking of waste ${ }^{4}$. Firstly introduced in 2001 when art. 22 of the Law 93/2001 implemented the art. 53-bis of the d.lgs. 22/1997 (the so-called decreto Ronchi), in 2006 organized activities for the illegal trafficking of waste became a definitive part of the Environmental Code. In particular, art. 260 of the Environmental Code punishes by imprisonment from one to six years any person who, in order to gain unfair profit through operations and preparation of means and organized continuing activities, sells, receives, transports, exports, imports or otherwise improperly handles large quantities of waste. If the waste is highly radioactive, the sanction is harsher, punishing violators with imprisonment from three to eight years. It should be noted that before the approval of this law, nobody had been seriously punished for the crime of illegal trafficking of waste. Since then, criminal enforcement has made an important step forward and has enabled disbanding some of the most active national and transnational criminal organizations.

\footnotetext{
2 This estimation was simply obtained from the difference between the amount of generated and managed waste (14.3 million tons) multiplied by an average cost for waste management (220 Euro per ton). Using a different methodology, Transcrime estimates revenues between 326 and 522 million Euro.

3 For example, the Art. 256 of the Environmental Code punishes "whoever carries out an activity of collection, transport, recovery, disposal, trade and brokerage of waste without the permit, registration or communication based on Articles 208, 209, 210, 211, 212, 214, 215 and 216 shall be punished by: a) arrest from three months to one year or fined from 2600 to 26000 Euro for non-dangerous waste; b) arrest from six months to two years and a fine from 2600 to 26000 Euro for dangerous waste". It is an abstract endangerment offence punishing the exercise of activity out of the preventive control of the public administration. In particular, it is a misdemeanor and can be committed intentionally or negligently.

4 A recent law (Law 6/ 2014) was introduced into the Environmental Code Article 256 bis on the "Illegal burning of waste," which punishes with imprisonment from two to five years whoever sets fire to waste abandoned or deposited in an uncontrolled manner in unauthorized areas.
} 
Studying the effectiveness of the enforcement of environmental laws is an important research question for several reasons. There is, in fact, an ongoing policy debate, especially at the European level, whether to further strengthen criminal enforcement in the context of environmental law or not (Faure 2004). However, given the mixed and heterogeneous empirical findings, neither proponents nor opponents of stiffer sanctions are able to base their arguments on strong empirical grounds.

Therefore, in this work we attempt to answer the following research questions: i) what were the main determinants of organized illegal trafficking of waste in Italy over the period 2002-2013 and ii) to what extent is the existing enforcement system effective in deterring it? The present paper contributes to the existing literature on environmental crime in several ways. First, it explicitly analyzes a specific type of environmental crime, which presents the higher degree of sanctioning regime in the Italian environmental legislation. Second, Italy represents a quite important country study because of the strong presence of mafia clans and organized crime systems in the illegal market. Finally, our empirical analysis is based on a unique dataset that covers the total number of reported investigations related to the organized activities for the illegal trafficking of waste (art. 260 of the Environmental Code) over the considered period.

The remainder of the paper proceeds as follows. Section 2 outlines the main characteristics of the organized illegal trafficking of waste in Italy. Section 3 reviews the main theoretical and empirical literature and points out the main hypothesis to be tested. Section 4 describes the dataset and the empirical model, while the results are illustrated in Section 5. Finally, Section 6 summarizes and concludes the paper.

\section{The organized illegal trafficking of waste in Italy}

\subsection{Economic and institutional drivers}

Illegal trafficking of waste arises when higher profits are expected compared to legal options of recycling or disposal, combined with institutional or enforcement failure. From an economic point of view, this environmental crime is mainly motivated by cost-saving decisions driven by the attempt: i) to reduce the relatively high costs of treatment and disposal of waste and ii) to take advantage of regional differences in environmental taxation (i.e., landfill and incineration taxes). A recent work of D'Amato et al. (2014) found that in Italy a stricter environmental taxation measured by the move from TARSU to TIA exerted a positive effect on illegal disposal and trafficking. However, it should be possible that higher environmental taxes could provide an economic incentive to maximize recycling; for example, Mazzanti and Montini (2014) found that more diffuse incentive based policy instruments, such as waste tariffs, might positively correlate to better waste management.

Another economic factor that can induce the illegal shipment of waste is the potential economic returns of waste as an export. In fact, several waste streams are shipped to countries outside the EU as 'second-hand goods' (i.e., primarily waste electrical and electronic equipment, end-of-life vehicles, but also car tires and other types of waste). The wide difference in prices between used and new products in these countries is one of the most important factors encouraging illegal shipments.

The illegal trafficking of waste may also be driven by other factors that have an institutional nature and are concerned with regulatory or enforcement failures. Firstly, in Italy, waste treatment and disposal plants are insufficient and are somewhat unevenly distributed at regional level. In Italy, every year the total production of waste amounts to almost 164 million tons with a treatment capacity of just over 150 million tons: specifically, there are 32.5 tons of municipal waste produced, 79.4 tons of nonhazardous waste, 41.9 tons of construction and demolition waste, and 9.6 tons of hazardous waste (Fise Assoambiente 2009) ${ }^{5}$. The geographical distribution of the waste treatment and disposal plants is concentrated in some areas of the country (mainly in the northern regions) with the consequence that there are territories (in the southern regions) where mafia clans and criminal organizations are the only actors able to manage waste disposal. For example, if we take into consideration the

\footnotetext{
5 Overall, there are 6404 waste recycling plants with a treatment capacity of 150800 tons and 403 waste disposal plants with a capacity of 20500 tons. To these numbers, must be added 686 landfills with a residual total disposal capacity of approximately 122600 tons.
} 
composting sector, there are 146 plants in the north, 52 plants in the south and only 42 plants in the center. Such a situation encourages the legal (and illegal) trafficking of waste often making the international transport less expensive than a long-distance treatment at home and paving the way for eco-criminal infiltrations.

Second, a national waste reduction policy as well as a systemic vision concerning both urban and hazardous waste are still missing in Italy. The urban waste management is under public local municipalities, which follow their own policies, however hazardous waste management is completely left to free market rules. Using a spatial analysis, Mazzanti and Montini (2014) have shown that the heterogeneous waste management and disposal performances inside Italy depend not only on the existence of a North-South divide, but also on the quality of waste policy and idiosyncratic socio-economic factors. The absence of a waste management policy based on political and administrative planning at the national level and coherent with a long-running industrial strategy, feeds institutional and regulatory uncertainty, which furthers the illegal trafficking of waste.

Finally, the implementation of an effective system of control in Italy is sometimes quite difficult for several reasons. First, the waste management cycle is characterized by many steps whose traceability is ensured by selfcertifications (the so-called formulary Fir), and so it is easily eluded and counterfeited ${ }^{6}$. Second, since monitoring and inspection activities are officially delegated to some regional environmental agencies (ARPA) without a sufficient financial budget and often lacking the necessary technical equipment, the challenge is therefore entirely left to the police force that, however, may investigate only when in possession of a notitia criminis. In addition, multiple police forces enact law enforcement at, both, national (Arma dei Carabinieri, Polizia di Stato, Guardia di Finanza, Corpo Forestale dello Stato) and local levels (Polizia Provinciale and Polizie Municipali), which quite often do not communicate and cooperate among each other. There is no doubt that the cooperation among all law enforcement authorities and prosecutors is the best weapon to fight illegal waste trafficking. In fact, as shown by the investigation named "Demeter" (which led to 49000 tons of hazardous waste seized in 64 countries), inter-force inquiries are the most effective strategy to uncover complex criminal organization. As a matter of fact, in the last few years this investigative cooperation has increased. For example, the Italian Customs Agency has stipulated some protocols to better coordinate its investigations with other police forces. Nowadays, such a cooperation also involves some waste Consortia (such as Polieco and Ecopneus), which in Italy are established by law and are responsible for waste collection and recycling. On the other hand, the challenge that Italian enforcers and prosecutors have to undertake, is frustrated by complex and ever-changing laws and wrong (or absent) political enactments.

\subsection{How does the illegal trafficking of waste work?}

The most common method used for evading controls and dumping hazardous waste with impunity in unsuitable areas or even recycling them into the production system is the so-called "giro bolla" ("invoice switch") system. In this scheme, waste materials are taken from the producer and transferred to either a storage center or intermediate stockpiling area, which then becomes the new producer of the waste materials. Here, documents accompanying the shipment are falsely modified and the waste materials declassified from hazardous to nonhazardous without undergoing any treatment. The documents are falsified by either using fake certificates or old certificates with a new date but the same code, which identifies the waste as non-hazardous. In other cases, this passage from the producer to a storage center is not even necessary, since the false documentation is delivered directly to the truck drivers (usually in parking areas along the highways) who transport the waste to the final disposal site. Falsifying these documents is obviously a crucial stage in the process and can be done in various ways: e.g., a false analysis provided by cooperative laboratories, forgery of loading/unloading records, improper use of identifying codes assigned to the waste materials, and so on. For example, a toxic solvent, which should be addressed to a landfill for hazardous waste, can be easily "transformed" into a harmless urban waste. Because of this counterfeit, the toxic solvent is, at best, addressed to a landfill for municipal waste or, at worst, it is thrown into an illegal landfill or recovered as compost to be used in farmlands.

\footnotetext{
6 Illegal shipment may take many forms such as: i) the transport without notifying the authorities of source and destination when such a notification is necessary; ii) the falsification of any documentation regarding waste loads or the not declaration of waste; iii) the mixing of certain types of waste; iv) the classification of hazardous waste as nonhazardous ('green-listed'); v) the shipping whilst falsely claiming that it comprises second-hand goods and it is therefore not subject to waste regulations.
} 
In Italy (but also in other EU countries) industrial waste represents $80 \%$ of the total amount of waste produced each year and it is also the most trafficked, both nationally and internationally. One of the key problems in the management of waste is that usually the processing and final disposal sites are too far from those of production. It is easy to predict that the further waste must transit, the easier it will be for traffickers to divert the waste into an illegal network. The most common technique used by the "merchants of poison" is the systematic falsification of the documents accompanying the waste (the so-called "giro-bolla") that converts, at least on paper, special and often dangerous waste into harmless waste (such as raw materials or simple agricultural fertilizers). Very often the "downgrading" of waste's hazardous status is implemented by mediators (such as owners of processing, storage or composting plants), chemical laboratories, public servants, etc. In fact, to improve the recycling and the energy recovery, the Italian law requires appropriate plants to process and recover the materials with chemical and physical treatments. Very often these treatment plants are used as a front for the illegal "downgrading" of waste, simulating the processing operations. In such a case, the waste enters into the plant with a code and comes out with another code, without being subjected to any real industrial treatment. Additionally, it is also an enormous cost saving for the waste producers, a huge profit for the illegal traffickers and a big public economic loss. In fact, the waste, both urban and special, should be considered as a raw material with its own intrinsic value. Letting these raw materials move into the illegal network implies, namely, a direct economic loss for the recycling industries (which lose waste to treat) and indirectly, the manufactures (which lose cheaper secondary raw materials for their own production). This is particularly true for a country like Italy, which has a long history in the field of recycling that, nowadays, is seriously endangered by the waste traffickers.

Recently, many inquiries have shown that a new way to manage waste illegally is emerging in Italy. In fact, some entrepreneurs have taken advantage of the so-called "simplified procedure" in waste disposal (art. 214 and D.Lgs.152/2006). Notwithstanding the current regulations, this procedure was introduced for some specific activities, which must be authorized by the local institution (i.e., provincia) and requires less bureaucratic fulfillments and controls. Born as an exception, this simplified procedure has quickly become the rule, evolving into an unintended subsidy for the illegal waste trafficking vendors. As a matter of fact, there are more and more plants operating under this administrative regime and many of them are accused of illegal waste trafficking.

Illegal waste trafficking is continuously changing. Nowadays, the falsification of documents is also used to commit tax frauds. The modus operandi is straightforward and effective: a waste management plant creates a new company with the specific goal to invoice false operations and to pay less tax. These companies (called "cartiere") usually disappear when law enforcers begin investigations. Generally, waste management firms involved in illegal trafficking act also on the legal market. Most of them are duly registered in the Chamber of Commerce and have the quality environmental certifications (in Italy, ISO 14001: 2004, EMAS, eco-label). Registration with the Association of Environmental Managers (Albo Gestori Ambientali) and the provision of a VAT code, often allow business operators to mask their illegal activities. At the same time, being without any criminal record allows a company to participate in all public procurement activities, including those for the management of municipal waste.

Although, in the public's opinion, mafia clans are the most important subjects involved in illegal waste trafficking, several inquiries have shown the fundamental role played in this field by the so called "white collars": businessmen, lawyers, politicians and public servants. Corruption is the crucial element that connects all these actors and this is particularly true in the waste sector, characterized by the grant of public licenses and authorizations. Moreover, this sector needs large economic investments and has to face a huge bureaucratic machine, which makes the environment even more susceptible to corruption. All these conditions hamper the competition and facilitate the formation of oligopolistic forces, where the strength of mafia intimidation is particularly effective. This could be a key element to understanding why in the south of Italy there are less treatment and recycling plants. As stated by investigators and by the Bank of Italy (2014), the opening of a waste management company can also hide money-laundering activity. Inquiries made by Italian Customs reveal that the illicit cross-border movements of waste are intertwined and follow the movement of legal goods. Consequently, it is 
important to follow the legal route to discover the illegal ones.

\subsection{Some descriptive facts about the organized illegal trafficking of waste in Italy}

Organized illegal trafficking of waste in Italy can be suitably illustrated with descriptive statistics. The number of yearly reported cases of organized illegal trafficking of waste is shown in Figure 1. The number of crimes sharply increased up to 2010 and reduce in the following years. It is worth noting that, in 2010, investigations of organized illegal trafficking activities of waste moved under the responsibility of the DNA (Direzione Nazionale Antimafia) ${ }^{7}$.

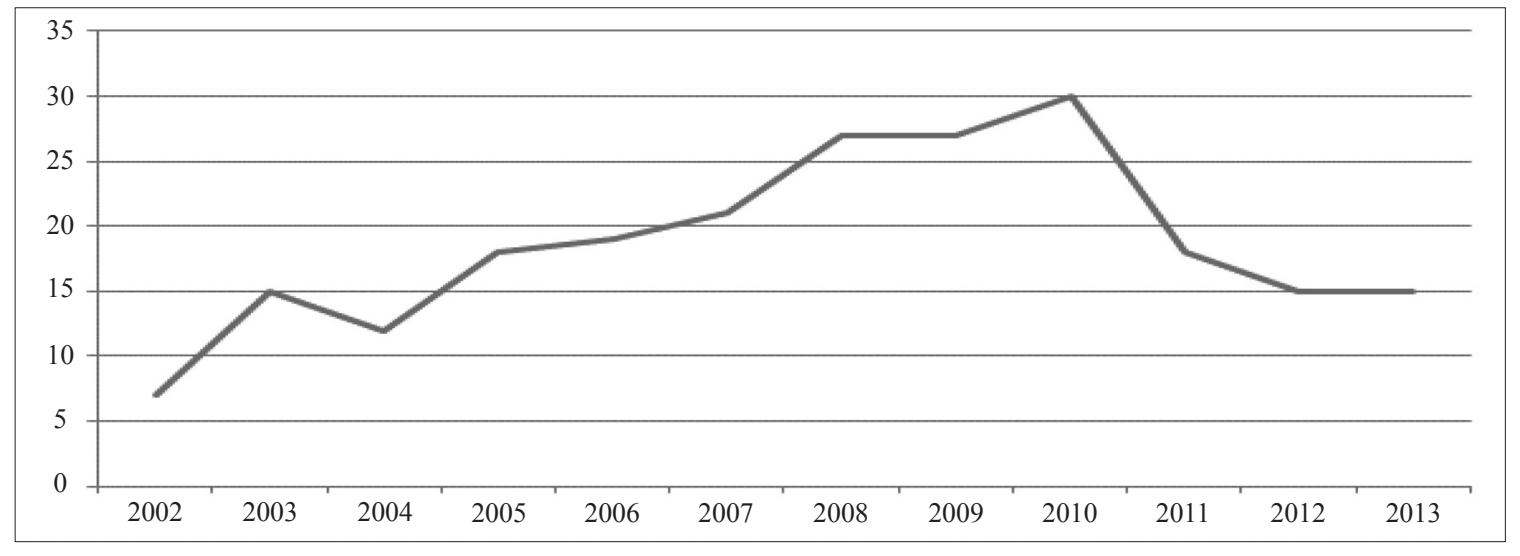

Fig.1. The total number of reported cases of organized illegal trafficking of waste by year

Source: authors's elaborations on Legambiente database

The shift of responsability of the investigations to the DDA (Direzioni Distrettuali Antimafia) and the reduction in the number of violations can be explained by the stronger cooperation between investigators, which has strenghtened the exchange of knowledge and information, however this has also generated some structural and organizational delays that have slowed down the investigation and enforcement process (Figure 2).

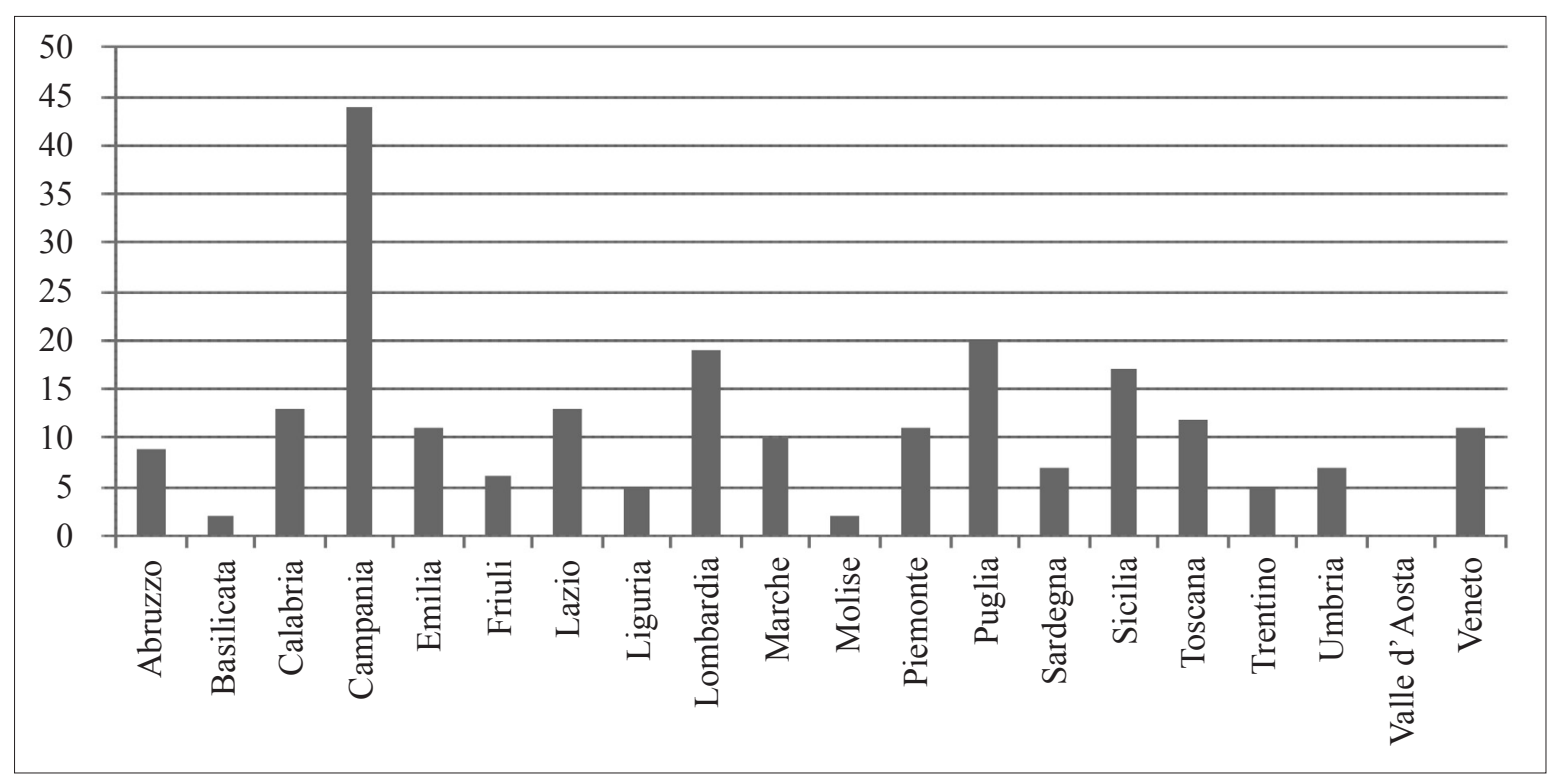

Fig.2. The total number of reported cases of organized illegal trafficking of waste by region (2002-2013)

Source: authors's elaborations on Legambiente database

\footnotetext{
7 The DNA comprehends twenty-six Direzioni Distrettuali Antimafia (DDA), who are in charge of mafia investigations.
} 
Reducing the total number of investigations at the regional level according to the location of the investigation office (Procura Distrettuale), reveals that this spike is driven by a small number of regions including Campania, Apulia, Lombardy and Sicily. These four regions, which cover $44.6 \%$ of the total number of investigations, are also the regions where most environmental violations in the entire waste cycle have been detected ${ }^{8}$. However, only half of the investigations involve only one region (113 out of 224). Looking at the degree of regional involvement of the investigations (Figure 3), we see that $23.7 \%$ of the reported cases refer up to three regions, $19.2 \%$ up to six regions and the remaining $7.6 \%$ involve between seven and ten regions. These figures show how the concentration of illegal activity is only apparent in a few regions; the organized activities for illegal trafficking of waste is a crime that spills beyond the region where the investigation starts, spreading throughout a large part of the national territory. In particular, the organized illegal trafficking of waste is a crime with a long "production chain" that requires several criminal professional skills linked by a network structure not limited to within a specific territory.

\begin{tabular}{|ccc|}
\hline Number of regions & Number of investigations & $\%$ \\
\hline One & 111 & 49,6 \\
Two & 28 & 12,5 \\
Three & 25 & 11,2 \\
Four & 26 & 11,6 \\
Five & 13 & 5,8 \\
Six & 4 & 1,8 \\
Seven & 10 & 4,5 \\
Eight & 3 & 1,3 \\
Nine & 2 & 0,9 \\
Ten & 2 & 0,9 \\
\hline Total & 224 & 100,0 \\
\hline
\end{tabular}

Fig.3. The number of regions involved in the investigations (2002-2013)

Source: authors's elaborations on Legambiente database

As the development of crime usually depends on several factors including the stringency of enforcement of the executive, it is of special interest to analyze the success of police in enforcing environmental criminal law in detail. Figure 4 shows the development of the number of offenders charged and the number of offenders arrested for the organized activity in illegal trafficking of waste. Similar to the number of reported crimes shown in Figure 1, we can see that the number of offenders arrested peaked in 2010 and reduced afterwards. Even in this case, a possible explanation can be given by the shift of the investigation responsability to the DNA. The two curves demonstrate different trends over time: while the curve indicating the number of charges is quite erratic, the curve illustrating arrests is more regular, which could be attributed to the fact that these arrested offenders represent the hard core of the criminal organizations, who, in order to promote their criminal design, need only a minimal informal support structure. The average number of offenders arrested for each investigation varies between 4 and 6 , which is consistent with what investigators consider sufficient to set up an organization of illegal trafficking of waste 9 .

\footnotetext{
8 In particular, Campania is all along the region with the highest number (953 only in 2013) of detected environmental crime in the waste cycle (Legambiente 2014).

9 It is worth noting that, in order to conduct organized activity for the illegal trafficking of waste, their needs to be at least one entrepreneur operating in the waste sector, a transportation company, a chemical laboratory, and one broker.
} 


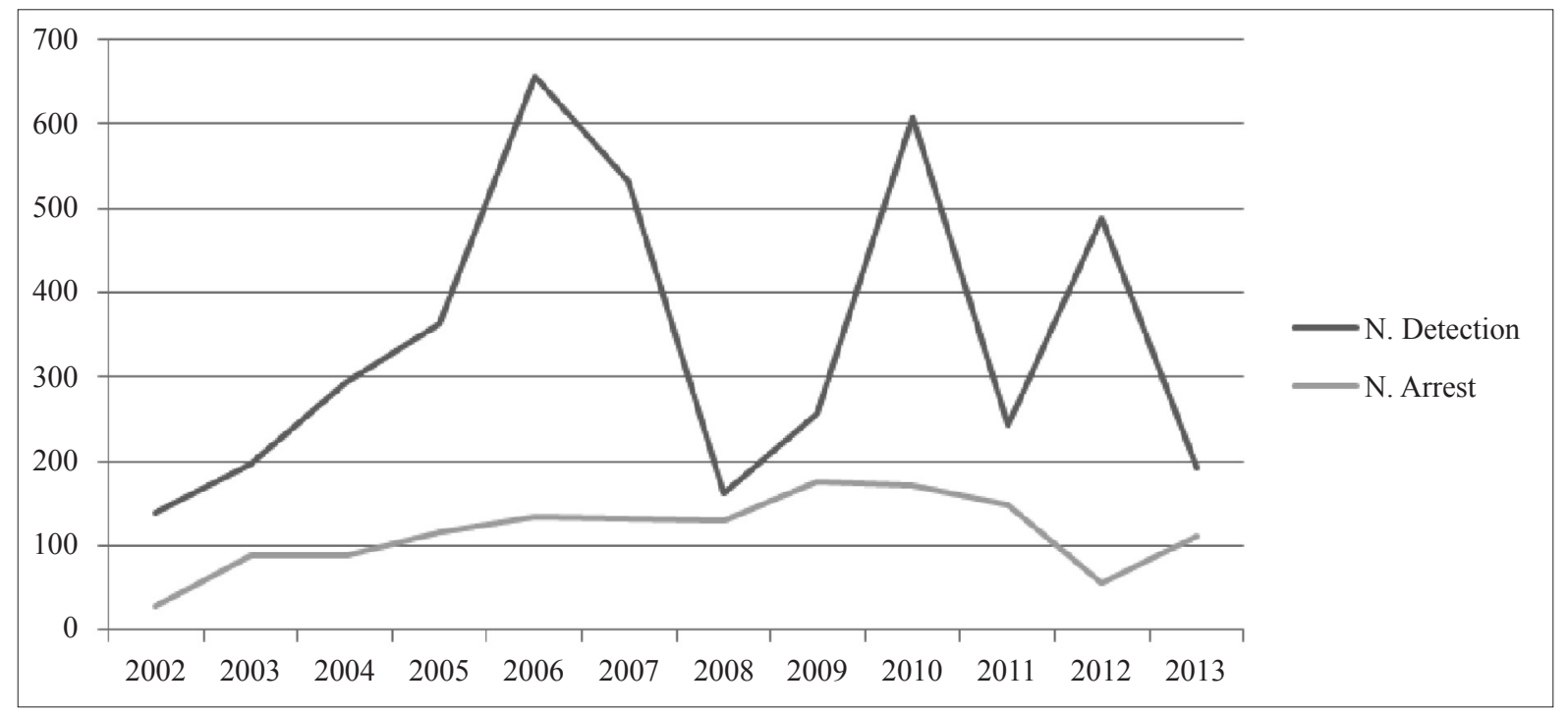

Fig.4. The total number of offenders charged and arrested

Source: authors's elaborations on Legambiente database

Figure 5 shows the evolution of reported cases of organized activity in illegal trafficking of waste by the nature (national or international) of the investigation. In the recent past, illegal waste trafficking has grown to a global scale. This is particularly true for specific kinds of waste (plastic, paper, metals, old tires, etc.), which are considered as raw materials and so draw big quotations in the Stoke Exchange. As a consequence, the Italian Customs Agency and other law enforcement authorities have improved controls and intelligence activity, gaining good results. The example of the year 2010, which saw the highest number of investigations and marked important outcomes also in terms of detections, clearly indicates this. The decrease in the number of inquiries, which can be seen in following years, must be read as a natural consequence of traffickers' reactions. In fact, to protect their business and escape the strict controls at Italian harbors, the traffickers shifted their route to other countries, such as Slovenia and Albania.

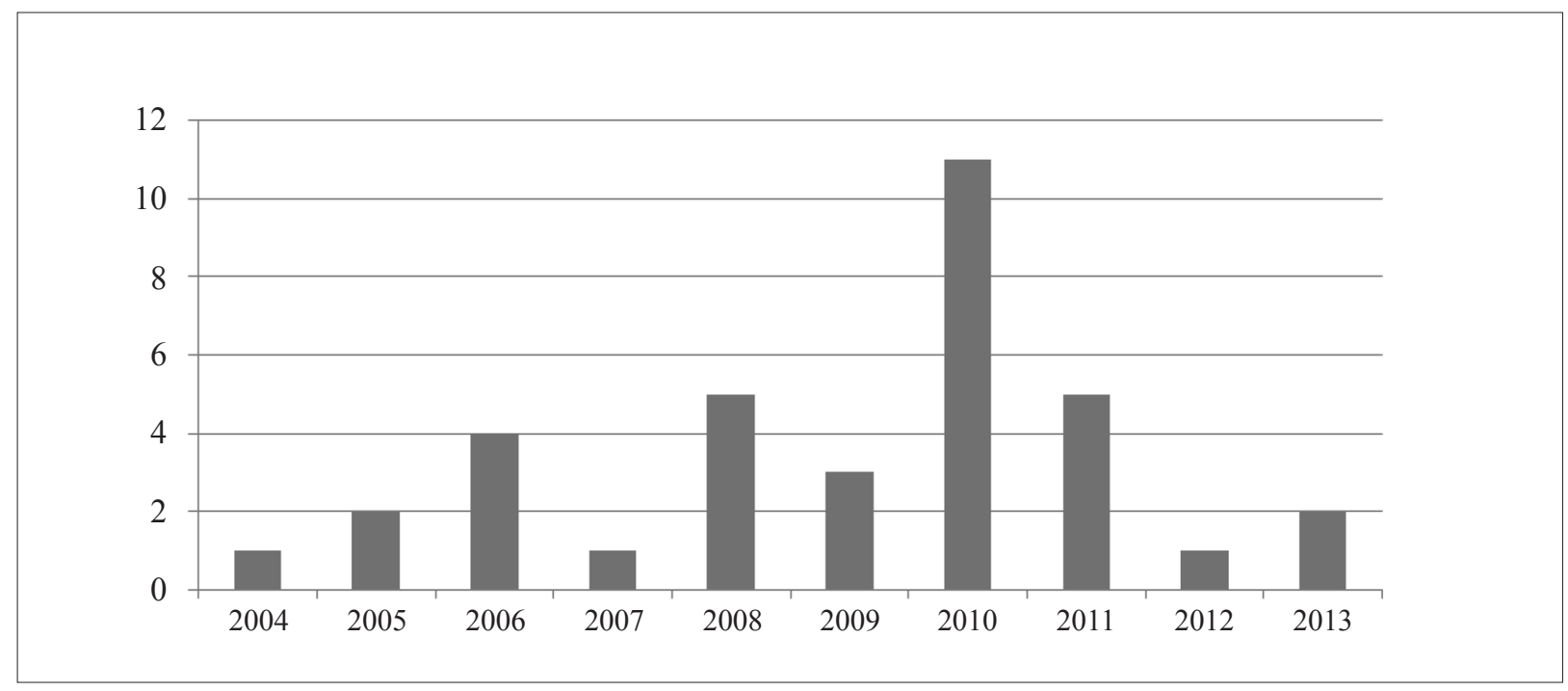

Fig.5. The number of international reported cases of organized illegal trafficking of waste by year

Source: authors's elaborations on Legambiente database

Our figures on the illegal export of waste slightly differ from the statistics collected by the Italian Customs 
Authority. If we consider not only the investigations for the organized activities for the illegal trafficking (art. 260 of the Environmental code), but also those for the illegal shipment of waste (art. 259 of the Environmental code), in the last three years Italian Customs seized more than 32 thousand tons of hazardous waste, of which 13600 ton was during 2012. The main ports of departures were: Genova, Venezia, Napoli, Gioia Tauro and Taranto. However, it should be stressed that such figures are just "the tip of the iceberg", since Italian ports ship yearly almost 4400000 containers, of which 750000 go to China. Far East countries seem to be the more important destinations for the Italian illegal shipments of hazardous waste. In 2012, 32.2\% of the total amount of seized waste was directed to China, $23.3 \%$ to India and $22.3 \%$ to South Korea. Behind the increase in the volume of waste shipment, there is the international demand for recovered materials from the rapid growth and industrialization of the major Asian economies (Figure 6). China is the dominant player, but India and Indonesia are also sourcing material from the EU to fuel domestic industries. In recent years, waste has increasingly been seen as a secondary raw material with economic value and with a significant role in supporting the decoupling of resource use from economic growth.

The European Commission (2011) estimated that, in 2008, the eco-industry of the EU 27 had a turnover of EUR 319 billion, 2.5\% of EU GDP, and employed 3.4 million people. Some waste streams have a surprising economic value. For example, the platinum embedded in catalytic converters of scrapped cars exported from Germany to Africa amounts to about a third of annual platinum use in Germany. A cost-benefit analysis shows that, not only the environment, but also the economy would strongly benefit from improvement legislation implementation across the EU. A study of the European Commission (2012) compares two scenarios for the period 2008-2020, one involving no progress in waste management and the other involving full implementation of eight pieces of EU waste legislation, and concludes that full implementation would mean cost savings of $€ 72$ billion per year. In addition, the study concludes that, by raising the level of the EU waste management sector to full compliance, the turnover of waste management and recycling would increase by $€ 42$ billion per year and over 400000 jobs would be created.

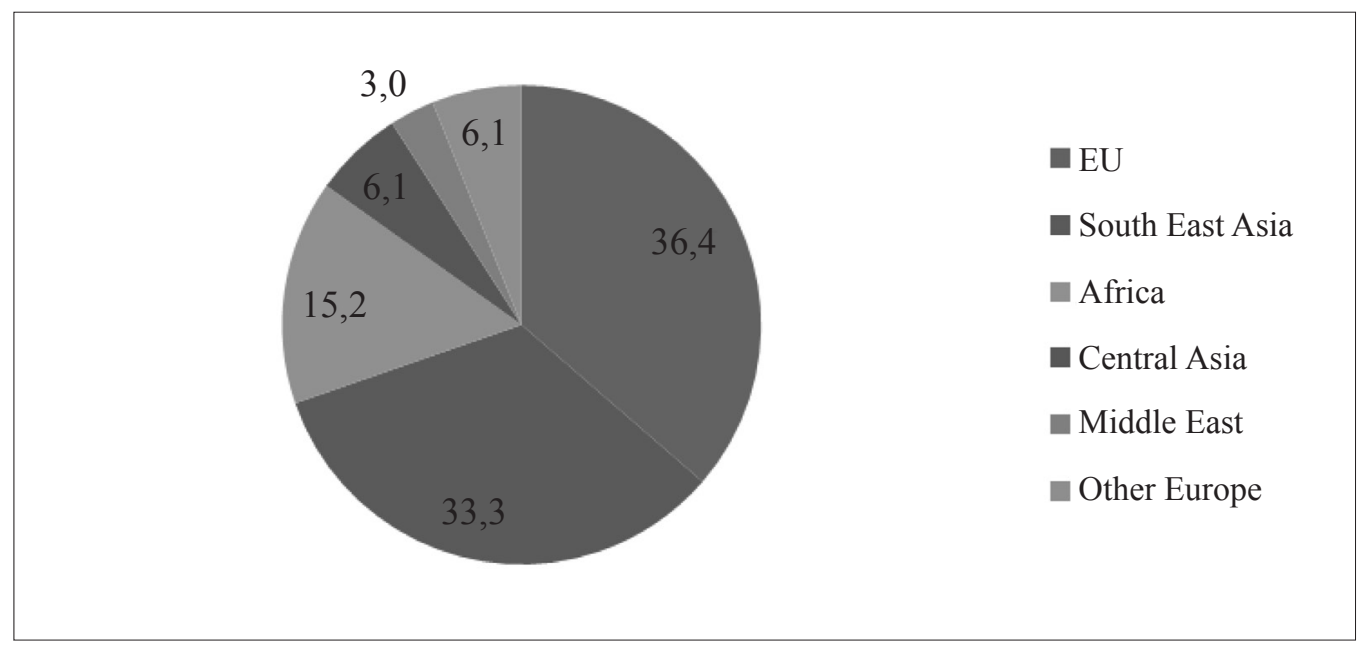

Fig.6. The number of international reported cases of organized illegal trafficking of waste by country (2002-2013)

Source: authors's elaborations on Legambiente database

Legambiente's report (2014) argues that, based on available data, 1.6 million tons of waste was seized in the last three years. To ship such a quantity of poisonous substances it would require more than 65 thousand trucks covering the same distance between Rome and Zurich $(886 \mathrm{~km})$. Since 2002, the total amount of seized waste was 15 million tons, almost equal to 525 thousand trucks covering a distance of more than $8000 \mathrm{~km}$. Figures 7 and 8 show the waste seized by business sector in both the national and international investigations. At the international level, we find that the illegal trafficking of waste seems to be concentrated in a few business sectors. Looking at Figure 7, it is possible to see that the highest share of illegal waste seized in the Italian ports is mainly composed by waste plastic (19.4\%), scrap metal (19.4\%), industrial studs and muds (12.9\%), textiles $(9.7 \%)$ and waste electrical and electronic equipment (WEEE) $(9.7 \%)$. 


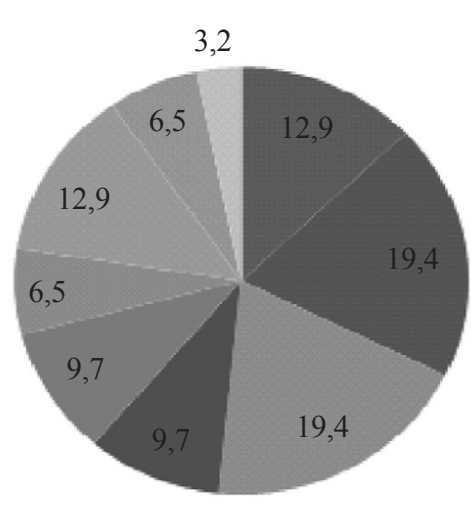

$\begin{array}{lll}\square \text { Industrial drosses and muds } & \square \text { Plastic waste } & \text { Metal waste } \\ \square \text { WEEE } & \text { Textiles waste } \\ \square \text { Miscellaneous waste } & \text { Construction and demolition waste } ₫ \text { Contaminated soil and stones }\end{array}$

Fig.7. Seized waste in national investigations by business sector (2002-2013)

Source: authors's elaborations on Legambiente database

The waste seized in national investigations belongs to different business sectors. Figure 8 shows that they are concentrated on industrial wastes and muds $(26.7 \%)$, metal waste $(11.1 \%)$ and animal and vegetal waste $(10.4 \%)$.

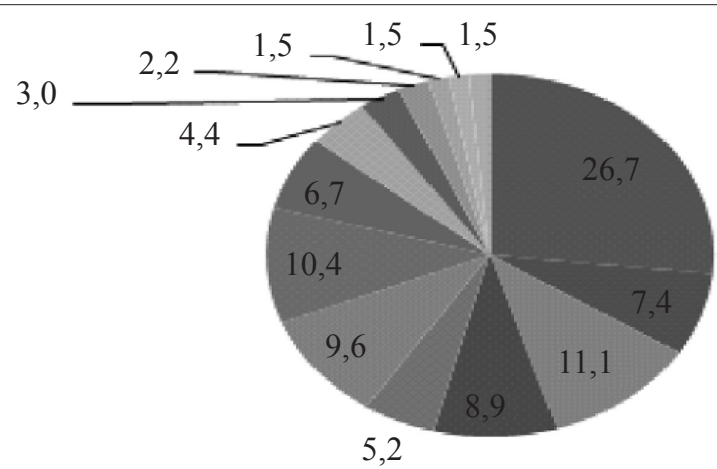

Industrial drosses and muds

Metal waste

- Plastic waste

Animal and vegetal wastes

- Wood and Paper wastes

- Chemical waste and lead batteries

- Car fluff
- Residues from (industrial) waste disposal operations

- Construction and demolition waste

- Miscellaneous waste

- Contaminated soil and stones

- PFU

- Textiles waste

- Municipal waste

Fig.8. Seized waste in international investigations by business sector (2002-2013)

Source: authors's elaborations on Legambiente database

Another important feature indicates the degree of organized crime's involvement in the illegal trafficking of wastes. Looking at Figure 9, we see that mafia clans only had a marginal role: in the period between 2002 and 2013 only $6.7 \%$ of reported cases registered the involvement of mafia clans. This figure is similar to that provided by the DNA: between July 2012 and June 2013 only 4 cases out of 123 refer to Mafia. The low degree of organized crime's involvement might be explained by the strong corporate nature of this type of crime that sees 
the involvement of entrepreneurs, transporters, and brokers, all of whom aim to meet the demand and supply of waste. In other words, there are some waste producers eager to dispose of their waste at low costs, and other firms are ready to earn money illegally disposing of all types of waste.

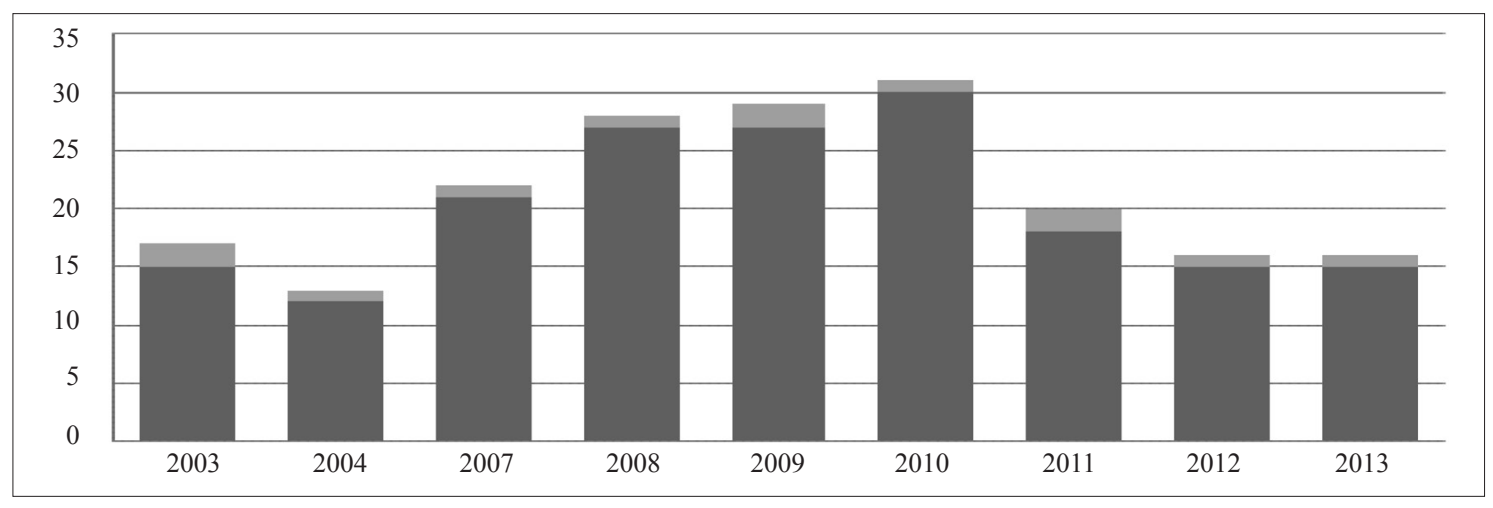

Fig.9. The presence of Mafia organization in the organized trafficking of waste

Source: authors's elaborations on Legambiente database

Mafia clans indeed are just one of the actors involved, but not the only one. As the data derived from our earlier investigations confirm, the most important role is played by entrepreneurs or, in general, economic players, who have captured the great and easy economic opportunity offered by the illegal waste management. This economic sector in fact was left to private improvisation by the Italian authorities, without any industrial point of view. Among all the Italian mafias, the Camorra syndicate was, and still is, the most involved ${ }^{10}$.

\section{Theoretical background and hypotheses}

The most recent theoretical and empirical literature related to waste management and disposal and to criminal enforcement is based on work by Almer and Goeschl (2010), in which they found evidence that criminal sanctions can play a relevant role in deterring environmental offences, and on the works by D'Amato et al. (2011) and by D'Amato and Zoli (2012), in which a public enforcement model is studied where risk neutral agents choose their compliance strategy according to the comparison between the expected benefits and the expected costs from illegal behavior. A number of papers, such as Sullivan (1987) and Fullerton and Kinnaman (1995) focus on illegal waste disposal, and some others, such as Shinkuma (2003) address costly enforcement and transaction costs, respectively.

To develop testable hypotheses that guide the empirical analysis in section 4, a range of determinants have been considered. This includes socio-economic, environmental and policy variables that might influence illegal behavior in general (Ehrlich 1973; Cornwell and Trumbull 1994) and environmental offences in particular (Hamilton 1996; Helland 1998; Stafford 2002; Eckert 2004). As it is well known (Becker 1968; Stigler 1970; Polinsky and Shavell 2000), the basic result of deterrence theory is that potential violators behave according to both the probability of detection and the severity of the sanction; thus, deterrence may be improved either by raising the sanction, or by increasing expenditures on enforcement to raise the likelihood that the violator will be captured ${ }^{11}$, or again by changing the legal rules to increase the probability of detection. Thus, based on the so-called deterrence hypothesis, potential offenders' illegal behaviors depend, inter alia, on risks and benefits of crime (Garoupa 1997). Assuming that potential criminals are cynical profit-maximizers who base their decisions on whether to commit a crime or not on an expected utility calculation, then they will comply with the

\footnotetext{
10 In particular, the Casalesi, a clan which took its name from a small town near Caserta, Casal di Principe. This clan is mostly responsible for the environmental disaster caused by the illegal waste dumped in the agricultural fields near the provinces of Caserta and Napoli ("Terra dei fuochi"). Last year, Domenico Bidognetti, the former chief of the Casalesi, was the first boss to be convicted for environmental disaster. For this eco-crime he was sentenced to 20 years in prison.

11 In Becker's model, the efficient level of crime is observable when the marginal cost of enforcement is equal to the marginal social benefit of crime reduced per unit of enforcement.
} 
law as long as their benefits outweigh their costs of compliance. As such, polluters are expected to comply with environmental regulations if the probability of being apprehended and sanctioned, coupled with the penalty imposed, is sufficiently high.

Therefore, with all of the above considerations, we might derive the following research hypotheses to be tested empirically:

Hypothesis 1: An increase in the enforcement effort results in, ceteris paribus, a lower number of violations; in other words, enforcement improves deterrence.

This hypothesis postulates that increasing enforcement efforts (i.e., judicial investigations, arrests) will lead to increased deterrence. Empirical studies have shown that a generally high level of enforcement implies a high level of deterrence. This is also the core of the prediction of Becker's model: increasing the expected costs of crime due to an increase in the probability of inspections, leads to lower rates of non-compliance (Gray and Deily 1996).

Hypothesis 2: An increase in economic activity leads, ceteris paribus, to a higher number of illegal waste trafficking violations.

The level of economic activity might influence illegal trafficking of waste in two ways (Almer and Goeschl 2010): in relation to scale and in relation to income. The former might be observable, since a greater production of waste corresponds with a higher level of economic activity and, in turn, this might lead to a higher degree of illegal trafficking (Eckert 2004; Stafford 2002). The latter effect might be observable since regions with higher incomes may care more about the environment and thus have a greater inclination to report misconducts than regions with lower incomes. Both mechanisms predict a higher number of violations for higher levels of economic activity.

Hypothesis 3: An increase in the legal opportunities of the population leads, ceteris paribus, to less (more) illegal waste trafficking violations.

The literature on the economics of crime has largely stressed the role of legal income opportunities in affecting the benefits and costs of crime. Theoretically, the relationship between the level and growth of income and crime is ambiguous. On the one hand, higher income opportunities may increase the chances for employment in the legal sector and, therefore, reduce the crime rate; on the other hand, higher income opportunities that improve the level of transferable assets in the community may potentially raise the revenues from crime. The rate of unemployment has also been considered as an indirect measure of the opportunity cost from crime. If legal income opportunities are less lucrative than potential gains from criminal activity, individuals will be more prone to engage in crime. Since unemployment may reduce expected legal earnings, it could generate a supplementary effect that induces individuals to commit more crime.

Hypothesis 4: An increase in the education level leads, ceteris paribus, to less (more) illegal waste trafficking violations.

Another economic factor that may affect the decision to engage in criminal activities is education. Primarily, higher levels of educational attainment, being associated with higher returns in the labor market, may increase the opportunity cost of criminal behavior. In addition, education may alter personal preferences in a way that affects decisions to engage in crime, bringing about a sort of "civilization" effect. In particular, Fajnzylber et al. (2002) suggest that education may increase the individual's moral stance, and then affect the individual's perception of crime. On the other hand, a higher level of education may reduce the cost of committing a crime or may raise the revenues of crime. Hence, the net effect of education attainment on criminal behavior is, a priori, ambiguous.

Hypothesis 5: An increase in the costs of treatment and disposal of waste lead, ceteris paribus, to more illegal waste trafficking violations. 
Illegal trafficking of waste arises when higher profits are expected compared to legal options of recycling or disposal, combined with regulatory or enforcement failure. The criminal behavior is driven, therefore, by an attempt to reduce the relatively high costs of legal treatment of waste, of legal disposal (i.e., landfill tax) and of transportation costs. D'Amato et al. (2014) found that higher costs paid on legal disposal of waste have a positive effect on illegal disposal.

Hypothesis 5: A more environmentally sound policy and an integrated system of waste management and disposal reduces, ceteris paribus, the incentive to illegally traffic waste.

The lack of adequate (and effectively enforced) waste management policies generates institutional and regulatory uncertainty, which fosters the illegal trafficking of waste. Mazzanti and Montini (2014) have shown that the heterogeneous waste management and disposal performances in Italy depend not only on the existence of a north-south divide, but also on the quality of waste policy and idiosyncratic socio-economic factors. A more effective waste management policy should require national political and administrative planning, in coordination with a long-term industrial strategy.

\section{Data description and empirical strategy}

\subsection{Data description}

Data on the organized illegal trafficking of waste were provided by the Osservatorio Ambiente e Legalità of Legambiente. Since the application of ex art 53 bis Decreto Ronchi (actually, art. 260 D.Lgs. 152/01), Legambiente started collecting information on the total number of investigations related to the organized activities of illegal waste trafficking (art. 260 of the Environmental Code). In particular, for each investigation, Legambiente's dataset contains information on the number of offenders detected, the number of offenders arrested, the number of firms involved in the investigation, the location of public prosecutors' offices, the type and the amount of seized waste and the type of investigation (national or international). From a methodological point of view, it is worth noting that the collection of data refers to the total number of investigations that were collected by the investigation authority and transferred to the prosecutor authority. Our dataset also considers all the investigations conducted by the entire set of investigation forces in charge of environmental crime. Given the nature of the data, they can be grouped at, both, province and region levels. However, in order to build a balanced panel, we have confined our analysis to annual observations of regional aggregations for the 20 Italian regions (NUTS2) over the period 2002 to 2013.

\subsection{Variables definition}

The dependent variable is the rate of crime, which is measured by the number of investigations related to organized illegal waste trafficking activities (art. 260 of the Environmental Code) per 100000 resident population in each region-year. In our empirical analysis, we use a set of explanatory variables divided into three groups: deterrence variables, waste market-related and socioeconomic variables. To address the deterrent effect on criminal behavior, we use two variables such as the charge rate and the arrest rate. The former is measured by the ratio of the number of offenders charged to the total number of offenders recorded and reflects the portion of offenders that are identified by legal authorities. The latter is defined as the ratio of the total number of offenders arrested to the total number of offenders recorded. These variables indicate the portion of offenders who have already received some kind of punishment, but do not reveal the certainty of their conviction. For both the deterrrence variables, we have also considered their squared terms in order to control for a possible non-monotonic relation.

To account for waste related variables, we use the number of waste treatment plants in each region and the per capita recycling (or recovery) rate. The first variable is a proxy for the cost of treatment and disposal of waste, while the second proxies the adoption of environmentally sound management policies at regional level. Finally, we complete our dataset by including a set of socioeconomic variables that reflect the legal income opportuni- 
ties of potential criminals. In particular, we insert into our model the Gross Domestic Product per capita at 2005 constant prices, the rate of growth of the real GDP at 2005 constant prices, the male unemployment rate and the share of population that has enrolled in secondary school ${ }^{12}$. A detailed description of the variables, their definition, as well as the source of data is provided in Table 1.

\subsection{Econometric methodology}

In this section we implement a simple model of environmental crime, which posits a relationship between annual reported crime in each region and region-level enforcement variables, plus some other control variables. The estimation equation takes the following form:

Incrime $_{i t}=a_{0}+$ Blncrime $_{i t-1}+X_{i t}^{\prime} \gamma+\mu_{i}+$ year $_{t}+\varepsilon_{i t}$

where the subscripts $i$ and $t$ represent region and time period, respectively. The dependent variable (lncrime) is the crime rate, while the explanatory variables are the lagged crime rate and a set $(\mathrm{X})$ of socioeconomic and waste specific variables characterizing the crime. The lagged crime rate in the previous year was inserted into the model in order to identify a possible dynamics in crime. As a matter of fact, the economic crime literature has identified the possibility of criminal hysteresis or inertia (Fajnzylber et al. 2002); in other words, higher crime today is associated with higher crime tomorrow. Past crime may affect current criminal behavior for several reasons. First, criminals can learn by doing, acquiring some level of adequate criminal know-how, which allows them to reduce their expected cost of carrying out criminal acts. Moreover, convicted criminals are likely to have less legal job opportunities, thus reducing their personal cost of participating in criminal activity and making the commission of crime more attractive. Variable $\mu_{\mathrm{i}}$ is a region fixed effect to control for some time-invariant regional characteristics that were omitted in the model but had an impact on crime rates over years; year $_{t}$ is a time effect that captures the common variations in crime rates across regions and removes the correlation amongst regions; Finally, $\varepsilon_{\mathrm{it}}$ stands for a well-behaved error term distributed $\operatorname{IID}\left(0, \sigma^{2}\right)$.

The dependent variables and all explanatory variables, except for the number of incinerators, were natural logged to alleviate the problem caused by the skewed distributions of some variables. Another advantage of doing this was to simplify the calculation of the percentage change of crime rates for a one percent change in each explanatory variable (elasticity). The number of incinerators was not logged as the time series contained a substantial amount of zeros. We estimate our model using the first-differenced GMM procedure (Arellano and Bond 1991; Arellano and Bover, 1995). This estimator allows controlling for (weak) endogeneity by using the instrumental variables, which consist of appropriate lagged values of the explanatory variables. The consistency of the GMM estimator crucially depends on the validity of the instruments. We address this issue by considering two specification tests suggested by Arellano and Bond (1991). The first is the Sargan test of over identifying restrictions, which tests the null hypothesis of the overall validity of the instruments used. Failure to reject this null hypothesis gives support to the model. The second test examines the hypothesis that the error term is not serially correlated. We test the null hypothesis that the differenced error term is first and second order serially correlated. Failure to reject the null hypothesis of no second-order serial correlation implies that the original error term is serially uncorrelated and the moment conditions are correctly specified.

\subsection{Results}

Table 3 provides the GMM estimates obtained using the Arellano-Bond methodology. Three test statistics are reported: (i) Sargan test of over identifying restrictions; (ii) first order serial correlation test and (iii) second order serial correlation test. In Columns (i) and (iv) of table 2, the reported results do not control for socioeconomic and waste specific variables. In particular, estimates show that there is no crime persistence, with the coefficient of the lagged dependent variable being negatively and statistically significant. Both charge and arrest rates are positive and statistically significant. This result is quite unexpected and different with respect to

\footnotetext{
12 As there is great support in the general crime literature that different socioeconomic variables play an important role in explaining the amount of crime, we additionally tested the following list of variables: population density, value added of manufacturing sector, number of manufacturing firms, rate of irregular workers and income inequality. However, none of these seem to have a significant influence on environmental crime.
} 
the majority of the existing literature, because the cost of breaking the law, as measured by the charge to arrest ratio, should reduce the crime rate. However, the negative and significant coefficients of both squared terms reveal the existence of a hump shaped relation between organized illegal trafficking of waste and law enforcement efforts. In line with D'Amato et al. (2014), our result indicates that the influence of law enforcement on the organized illegal trafficking of waste can only affect criminal activities up to a certain threshold and a deterrence effect on criminal behavior can only be achieved to such a level.

Columns (ii) and (v) report the results obtained when the economic-specific covariates are inserted into the model. Now, we find that the lagged crime rate is negative and significant, meaning that there isn't a persistence of this type of crime over time in Italian regions. Also, the share of population that has enrolled in secondary school appears to be significantly and positively correlated with the crime rate. Similar to the results of other previous studies (Buonanno 2006), the positive effect of this variable may be attributed to the fact that a higher level of education may reduce the cost of committing a crime or may raise the revenues of crime. However, in this specific case, the positive relationship between levels of education and illegal trafficking of waste can be explained by the nature of the crime. Being a typical economic crime, it seems to be a prerogative of subjects with higher levels of education, since the covert illegal mechanisms require high skills and resourcefulness. The coefficients on GDP per capita, GDP growth rate and male unemployment rate are not statistically significant.

Finally, columns (iii) and (vi) of Table 2 present regressions that include two different indicators of waste management activities. As we can see, results are qualitatively similar to those presented above and, once again, suggest that the only significant determinants of organized illegal waste trafficking are the deterrence variables, the degree of educational attained, and the lagged crime rate.

Table 2. Determinants of organized illegal waste traff

\begin{tabular}{|c|c|c|c|c|c|c|}
\hline & (i) & (ii) & (iii) & (iv) & (v) & (vi) \\
\hline Crime rate lagged & $\begin{array}{l}-0.0685 \\
(-1.57)\end{array}$ & $\begin{array}{c}-0.184^{* * *} \\
(-7.13)\end{array}$ & $\begin{array}{c}-0.170^{* * *} \\
(-6.15)\end{array}$ & $\begin{array}{c}-0.0600 \\
(-1.58)\end{array}$ & $\begin{array}{c}-0.164^{* * *} \\
(-4.63)\end{array}$ & $\begin{array}{c}-0.152^{* * *} \\
(-3.96)\end{array}$ \\
\hline Charge rate & $\begin{array}{c}0.873^{* * *} \\
(4.42)\end{array}$ & $\begin{array}{c}0.654^{* * *} \\
(4.41)\end{array}$ & $\begin{array}{c}0.680^{* * *} \\
(4.76)\end{array}$ & & & \\
\hline Charge rate ${ }^{2}$ & $\begin{array}{c}-2.138^{* *} \\
(-2.90)\end{array}$ & $\begin{array}{l}-1.511^{*} \\
(-2.44)\end{array}$ & $\begin{array}{c}-1.585^{* *} \\
(-2.69)\end{array}$ & & & \\
\hline Arrest rate & & & & $\begin{array}{c}1.015^{* * *} \\
(4.21)\end{array}$ & $\begin{array}{c}1.042^{* * *} \\
(3.83)\end{array}$ & $\begin{array}{c}1.072^{* * * *} \\
(3.83)\end{array}$ \\
\hline Arrest rate $^{2}$ & & & & $\begin{array}{l}-2.232^{* *} \\
(-3.22)\end{array}$ & $\begin{array}{l}-3.119^{* *} \\
(-3.14)\end{array}$ & $\begin{array}{c}-3.236^{* *} \\
(-3.20)\end{array}$ \\
\hline GDP growth rate & & $\begin{array}{l}-4.787 \\
(-0.67)\end{array}$ & $\begin{array}{l}-5.511 \\
(-0.69)\end{array}$ & & $\begin{array}{l}-4.584 \\
(-0.69)\end{array}$ & $\begin{array}{l}-5.421 \\
(-0.72)\end{array}$ \\
\hline Average income & & $\begin{array}{r}-0.0400 \\
(-0.40)\end{array}$ & $\begin{array}{l}-0.0169 \\
(-0.15)\end{array}$ & & $\begin{array}{c}-0.0394 \\
(-0.37)\end{array}$ & $\begin{array}{c}-0.0316 \\
(-0.27)\end{array}$ \\
\hline Education attainment & & $\begin{array}{c}0.540^{* * *} \\
(5.67)\end{array}$ & $\begin{array}{c}0.533^{* * *} \\
(5.10)\end{array}$ & & $\begin{array}{c}0.400^{* * *} \\
(4.06)\end{array}$ & $\begin{array}{c}0.412^{* * * *} \\
(3.56)\end{array}$ \\
\hline Male unemployment rate & & $\begin{array}{c}-0.00557 \\
(-0.32)\end{array}$ & $\begin{array}{c}0.00278 \\
(0.13)\end{array}$ & & $\begin{array}{c}0.00829 \\
(0.50)\end{array}$ & $\begin{array}{l}0.0154 \\
(0.72)\end{array}$ \\
\hline Recycling rate & & & -0.0359 & & & -0.0377 \\
\hline
\end{tabular}




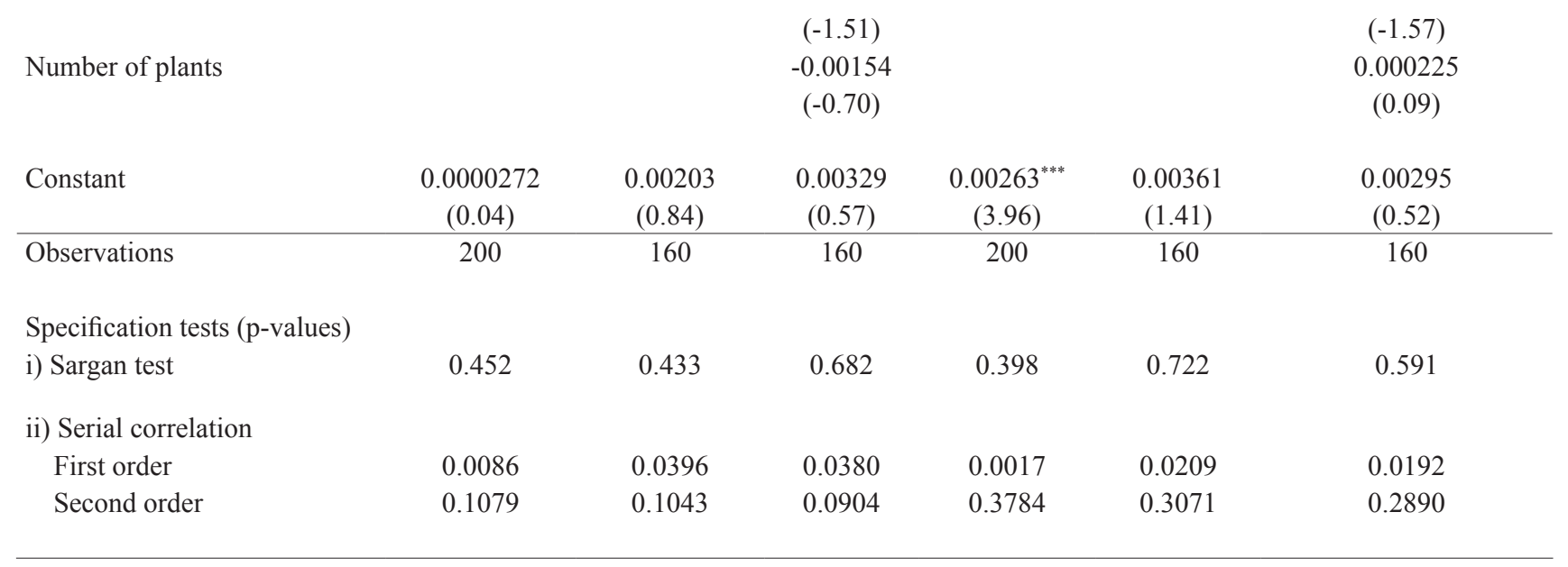

Note: Time dummies were included but omitted here. Robust standard errors are in parentheses. $* * * \mathrm{p}<0.01,{ }^{* *} \mathrm{p}<0.05,{ }^{*} \mathrm{p}<0.1$

$$
\text { Source: authors }
$$

With regards to the GMM specification tests, all regression models are supported by the Sargan test, which confirms the validity of the instruments used (i.e. the instruments are not correlated with the error terms). As expected, there is evidence for first-order serial correlation, while there is no evidence of second-order serial correlation.

\subsection{Territorial heterogeneity}

In order to account for the structural and relevant differences between the north-center and the south of Italy we estimate the crime equation for each of these territorial aggregations. Namely, we estimate a crime equation using a panel dataset for the 11 regions belonging to the north-center and a crime equation using a panel dataset for the remaining 8 regions belonging to the south of Italy. Table 3 displays coefficient estimates for northern regions.

Table 3. Determinants of organized illegal waste trafficking in the north-center of Italy

\begin{tabular}{|c|c|c|c|c|c|c|}
\hline & (i) & (ii) & (iii) & (iv) & (v) & (vi) \\
\hline Crime rate lagged & $\begin{array}{l}-0.157^{*} \\
(-2.21)\end{array}$ & $\begin{array}{c}-0.236^{* * *} \\
(-3.34)\end{array}$ & $\begin{array}{l}-0.242^{* *} \\
(-2.61)\end{array}$ & $\begin{array}{l}-0.124 \\
(-1.73)\end{array}$ & $\begin{array}{l}-0.144^{* *} \\
(-2.59)\end{array}$ & $\begin{array}{l}-0.152^{* *} \\
(-2.61)\end{array}$ \\
\hline Charge rate & $\begin{array}{c}0.467^{* * *} \\
(2.76)\end{array}$ & $\begin{array}{l}0.360^{*} \\
(2.33)\end{array}$ & $\begin{array}{l}0.426^{* *} \\
(3.27)\end{array}$ & & & \\
\hline Charge rate $^{2}$ & $\begin{array}{l}-0.607 \\
(-0.77)\end{array}$ & $\begin{array}{l}-0.295 \\
(-0.34)\end{array}$ & $\begin{array}{l}-0.437 \\
(-0.64)\end{array}$ & & & \\
\hline Arrest rate & & & & $\begin{array}{c}0.821^{* *} \\
(2.74)\end{array}$ & $\begin{array}{l}1.152^{* *} \\
(3.12)\end{array}$ & $\begin{array}{c}1.109^{* *} \\
(3.12)\end{array}$ \\
\hline Arrest rate $^{2}$ & & & & $\begin{array}{l}-2.180 \\
(-1.56)\end{array}$ & $\begin{array}{c}-4.666^{* *} \\
(-2.82)\end{array}$ & $\begin{array}{c}-4.432^{* *} \\
(-2.83)\end{array}$ \\
\hline GDP growth rate & & $\begin{array}{l}1.461 \\
(0.32)\end{array}$ & $\begin{array}{l}1.420 \\
(0.24)\end{array}$ & & $\begin{array}{l}1.605 \\
(0.24)\end{array}$ & $\begin{array}{l}1.437 \\
(0.22)\end{array}$ \\
\hline Average income & & $\begin{array}{c}-0.0931 \\
(-1.80)\end{array}$ & $\begin{array}{c}-0.0244 \\
(-0.36)\end{array}$ & & $\begin{array}{l}-0.125^{* *} \\
(-3.22)\end{array}$ & $\begin{array}{l}-0.100^{*} \\
(-2.54)\end{array}$ \\
\hline Education attainment & & $0.561^{* * *}$ & $0.460^{* * *}$ & & $0.375^{* * *}$ & $0.352^{* * *}$ \\
\hline
\end{tabular}




\begin{tabular}{lcccccc} 
Constant & $\begin{array}{c}0.000904 \\
(-1.00)\end{array}$ & $\begin{array}{c}0.00203 \\
(1.36)\end{array}$ & $\begin{array}{c}0.0167 \\
(1.76)\end{array}$ & $\begin{array}{c}0.00138^{* *} \\
(2.75)\end{array}$ & $\begin{array}{c}0.00118 \\
(0.79)\end{array}$ & $\begin{array}{c}0.00710 \\
(1.08)\end{array}$ \\
\hline Observations & 120 & 96 & 96 & 120 & 96 & 96 \\
& & & & & \\
Specification tests(p-values) & & & & & 0.244 & 0.32 \\
$\begin{array}{l}\text { i) Sargan test } \\
\text { ii) Serial correlation }\end{array}$ & 0.46 & 0.541 & 0.323 & 0.291 & & 0.0134 \\
$\quad$ First order & 0.0126 & 0.0342 & 0.0580 & 0.0085 & 0.0124 \\
$\quad$ Second order & 0.1334 & 0.1604 & 0.1366 & 0.6157 & 0.2107 & 0.1676 \\
& & & & & &
\end{tabular}

Note: Time dummies were included but omitted here. Robust standard errors are in parentheses. $* * * \mathrm{p}<0.01, * * \mathrm{p}<0.05, * \mathrm{p}<0.1$

With the exception of the model in column (iv), the lagged crime rate has a significantly negative effect in all models, indicating the absence of any persistence in crime, but past crime seems to reduce current criminal behavior. Furthermore, the results for both the charge rate and the arrest rate are uniformly positive and significant: an increase in both law deterrence variables would increase crime rate. Only the squared term of the arrest rate is negative and significant. Our findings indicate that law enforcement variables do not, in general, affect a significant deterrence on criminal behavior. Education attainment exhibits a positive and a significant effect on crime rate, indicating that, as previously found, the incidence of crime is greater, the greater the share of population that has enrolled in secondary school. It is worth noting that our findings show that an average income exhibits a negative and significant coefficient (columns $\mathrm{v}$ and vi). This means that, in the north-center, improvements in the overall economic condition increase the chances for employment in the legal sector and, thus reduce crime rates.

The results show that the crime rate in the north-center area is also driven by the per capita recycling and recovery rate. In the northern regions, recycling and recovery policies seem to be the best instruments to prevent crime, because they drastically reduce the use of both landfills and extensive commutes around the country; two action areas conducive to enabling organized crime. Empirical evidence shows that in those regions where waste management policy is more virtuous (i.e., Trentino, Friuli V. G. and Marche), the propensity to commit this type of crime is much lower. For example, in 2013 the above-quoted regions registered the lowest number of reported environmental crimes (Legambiente 2014).

The picture slightly changes when we consider empirical results for southern regions, as displayed in Table 4. First, lagged crime rate is not always statistically significant. In addition, as for the deterrence variables, we find that in the southern regions of Italy law enforcement measures related to the organized trafficking of waste do not exert significant deterrence on the criminal behavior. In particular, both the charge rate and the arrest rate are always positive and significant while their squared terms exert a negative and statistically significant effect on crime rates. In addition, in models (v) and (vi) the coefficient for education attainment is negative and significant indicating that more educated people have a higher moral stance or less time available to participate in illegal criminal activities, thus resulting in fewer perpetrated crimes. 
Finally, our proxy for the cost of waste disposal exhibits a positive and significant effect on crime rate, indicating that the incidence of crime rises, the higher the plant endowment in the region is. In those regions where the presence of organized crime is higher and where waste management policy is much more influenced by corruption, waste treatment plants are used to intercept waste demand and to channel it mainly towards illegal outlets. As is also often shown by police investigations, landfills and waste treatment plants are means used to mask illegal operations of waste management.

Table 4. Determinants of organized illegal waste trafficking in the south of Italy

\begin{tabular}{|c|c|c|c|c|c|c|}
\hline & (i) & (ii) & (iii) & (iv) & (v) & (vi) \\
\hline & D.L_CR & D.L_CR & D.L_CR & D.L_CR & D.L_CR & D.L_CR \\
\hline Crime rate lagged & $\begin{array}{c}-0.0839^{* * * *} \\
(-3.65)\end{array}$ & $\begin{array}{c}-0.0943^{* * *} \\
(-3.98)\end{array}$ & $\begin{array}{l}-0.195^{*} \\
(-2.10)\end{array}$ & $\begin{array}{l}-0.194^{*} \\
(-2.18)\end{array}$ & $\begin{array}{l}-0.138 \\
(-1.81)\end{array}$ & $\begin{array}{l}-0.117 \\
(-1.92)\end{array}$ \\
\hline Charge rate & $\begin{array}{l}1.205^{* *} \\
(3.19)\end{array}$ & & $\begin{array}{l}0.822^{* *} \\
(2.80)\end{array}$ & $\begin{array}{l}0.782^{* *} \\
(2.87)\end{array}$ & & \\
\hline Charge rate ${ }^{2}$ & $\begin{array}{l}-3.347^{*} \\
(-2.48)\end{array}$ & & $\begin{array}{l}-2.054^{*} \\
(-2.05)\end{array}$ & $\begin{array}{l}-1.782^{*} \\
(-2.32)\end{array}$ & & \\
\hline Arrest rate & & $\begin{array}{c}1.460^{* * *} \\
(3.71)\end{array}$ & & & $\begin{array}{c}1.350^{* * *} \\
(3.50)\end{array}$ & $\begin{array}{l}1.348^{* *} \\
(3.23)\end{array}$ \\
\hline Arrest rate ${ }^{2}$ & & $\begin{array}{c}-3.041^{* * *} \\
(-3.36)\end{array}$ & & & $\begin{array}{c}-3.308^{* * *} \\
(-3.57)\end{array}$ & $\begin{array}{c}-3.347^{* * *} \\
(-3.43)\end{array}$ \\
\hline GDP growth rate & & & $\begin{array}{l}11.99 \\
(1.43)\end{array}$ & $\begin{array}{l}13.80 \\
(1.59)\end{array}$ & $\begin{array}{l}8.038 \\
(0.97)\end{array}$ & $\begin{array}{l}8.177 \\
(1.05)\end{array}$ \\
\hline Average income & & & $\begin{array}{l}-0.696 \\
(-0.83)\end{array}$ & $\begin{array}{l}-0.831 \\
(-1.06)\end{array}$ & $\begin{array}{l}-0.204 \\
(-0.27)\end{array}$ & $\begin{array}{l}-0.204 \\
(-0.32)\end{array}$ \\
\hline Education attainment & & & $\begin{array}{l}-0.525 \\
(-0.66)\end{array}$ & $\begin{array}{l}-0.403 \\
(-0.57)\end{array}$ & $\begin{array}{c}-1.111^{* *} \\
(-2.60)\end{array}$ & $\begin{array}{l}-1.101^{*} \\
(-2.46)\end{array}$ \\
\hline Male unemployment rate & & & $\begin{array}{c}0.00247 \\
(0.09)\end{array}$ & $\begin{array}{c}0.00378 \\
(0.13)\end{array}$ & $\begin{array}{c}-0.00728 \\
(-0.27)\end{array}$ & $\begin{array}{c}-0.000636 \\
(-0.02)\end{array}$ \\
\hline Recycling rate & & & & $\begin{array}{l}-0.0317 \\
(-1.33)\end{array}$ & & $\begin{array}{c}-0.0326 \\
(-0.85)\end{array}$ \\
\hline Number of plants & & & & $\begin{array}{r}0.0146^{*} \\
(2.10)\end{array}$ & & $\begin{array}{c}0.00564 \\
(0.79)\end{array}$ \\
\hline Constant & $\begin{array}{c}0.000688 \\
(0.90)\end{array}$ & $\begin{array}{c}0.00430^{* * *} \\
(3.35)\end{array}$ & $\begin{array}{c}0.0176 \\
(1.44)\end{array}$ & $\begin{array}{c}0.00685 \\
(0.56)\end{array}$ & $\begin{array}{c}0.0163 \\
(1.55)\end{array}$ & $\begin{array}{c}0.0166 \\
(1.02)\end{array}$ \\
\hline Observations & 80 & 80 & 64 & 64 & 64 & 64 \\
\hline \multicolumn{7}{|l|}{ Specification tests(p-values) } \\
\hline ii) Serial correlation & 0.137 & 0.061 & 0.327 & 0.205 & 0.188 & 0.267 \\
\hline First order & 0.0455 & 0.0812 & 0.0772 & 0.0258 & 0.0897 & 0.0772 \\
\hline Second order & 0.1609 & 0.2274 & 0.2119 & 0.1439 & 0.1093 & 0.2119 \\
\hline
\end{tabular}

Note: Time dummies were included but omitted here. Robust standard errors are in parentheses. ${ }^{* * *} \mathrm{p}<0.01,{ }^{* *} \mathrm{p}<0.05,{ }^{*} \mathrm{p}<0.1$ 


\section{Conclusions}

The present paper contributes to a better understanding of the possible determinants relative to a still empirically unexplored type of environmental crime, i.e. the organized activities for the illegal trafficking of waste (art. 260, d.lgs. 152/2006). This is one of the most dangerous eco-crimes that poses not only a serious threat to the environment and human health, but has also become one of the causes for social and economic instability. The obtained results reveal that, in most Italian regions, enforcement activities do not exert significant deterrence on criminal behaviors. A negative relationship between enforcement and illegal trafficking of waste can be identified only for very high levels of enforcement efforts. Moreover, the outcomes show that the major determinants of illegal trafficking of waste rate differ between northern-central and southern regions, confirming the existence of a regional dualism. In particular, while in the north-center area the crime rate is positively related to level of education and negatively to the adoption of environmentally sound policies, in southern regions the organized activities for illegal trafficking are negatively related to the education attainment and positively to the endowment of waste management plants.

If in the north of Italy, the best plant equipment is linked to a better management of the entire waste cycle, as shown by the higher standards of recycling rate, in the south, the stubborn presence of various mafias and organized crime systems are able to move the waste management plants more towards personal interests and illegal practices. Therefore, we can argue that the presence of an adequate plant facility is important but not sufficient without both an effective policy aimed to prevent and contrast organized crime and strong social control processes at local level.

Also, in the north the positive relationship between levels of education and illegal trafficking of waste can be easily explained by the nature of the crime. Being a typical economic crime, it seems to attract subjects with higher levels of education, since the covert illegal mechanisms require high skills and resourcefulness. Unlike other forms of illegal trafficking, in order to operate effectively, operators must know the legal market and its dynamics, the complex legislation, and the weaknesses of the control systems. Almost all the investigations completed so far (since 2002) show that the falsification of, both, documentation (the so-called formulari) and chemical-physical analysis is a constant practice. In addition, other sophisticated types of crimes, such as, corruption in the public procurement system, fraud in public procurements, and money laundering activities are emerging, supporting the fact that these are all crimes that require high skills and well-defined professional abilities.

Finally, in terms of policy suggestions, the evidence obtained allows us to support the hypothesis that, in Italy, a better integrated system of waste management and disposal in coordination with a long-term industrial strategy, should be urgently implemented in order to restrict the flows of illegal trafficking of waste. The challenges at stake are certainly serious. Creating an environment for the successful management of the situation requires an integrated approach linking economic, legal, and institutional factors. The need for a more sustainable waste management policy in Italy is driving pressure on institutions, policy makers and governments to further cooperate toward a more circular economy, where waste can be eliminated and resources can be used in a more efficient and sustainable way.

\section{References}

Almer, C.; Goeschl T. 2010. Environmental crime and punishment: Empirical evidence from the German penal code, Land Economics 86: 707-26.

Arellano, M.; Bond, S. 1991. Some Tests of Specification for Panel Data: Monte Carlo Evidence and an Application to Employment Equations, Review of Economic Studies, 58(2): 277-297. DOI: 10.2307/2297968

Arellano, M.; Bover, O. 1995. Another Look at the Instrumental Variable Estimation of Error-Components Models, Journal of Econometrics 68(1): 29-51. DOI: http://dx.doi.org/10.1016/0304-4076(94)01642-D

Bank of Italy 2014. Annual Report Financial Intelligence Unit. Banca d'Italia. 
Becker, G. S. 1968. Crime and Punishment: An Economic Approach, The Journal of Political Economy 76(2): 169-217. DOI: $10.1086 / 259394$

Buonanno, P. 2006. Crime and Labour Market Opportunities in Italy (1993-2002), Labour 601-624. DOI: 10.1111/j.14679914.2006.00346.x

Cornwell C.; Trumbull W. 1994. Estimating the Economic Model of Crime with Panel Data, The Review of Economics and Statistics 76(2): 360-366. DOI: $10.2307 / 2109893$

D’Amato A.; Mazzanti, M.; Nicolli, F.; Zoli M. 2014. Illegal waste disposal, territorial enforcement and policy. Evidence from regional data, SEEDS working paper series n. 03. Available on the Internet: http://www.sustainability-seeds.org/papers/RePec/srt/wpaper/0314. pdf

D'Amato, A.; Zoli, M. 2012. Illegal Waste Disposal in the Time of the Mafia: a Tale of Enforcement and Social Well Being, Journal of Environmental Planning and Management 55: 637-655. DOI: 10.1080/1943815X.2014.962549

Eckert, H. 2004. Inspections, warnings and compliance: the case of petroleum storage regulation, Journal of Environmental Economics and Management 47: 232-259.

Ehrlich, I.1973. Participation in Illegitimate Activities: A Theoretical and Empirical Investigation, The Journal of Political Economy 81(3): 521-565. Available on the Internet: http://www.journals.uchicago.edu/JPE/home.html

European Commission 2011. Implementing EU Waste legislation for green growth. Final report, European Commission DG ENV, 29 November 2011. Available on the Internet: http://ec.europa.eu/environment/waste/studies/pdf/study\%2012\%20FINAL\%20REPORT.pdf

European Commission 2012, Generation, treatment and transboundary shipment of hazardous waste and other waste in the Member States of the European Union, 2007-2009, Report from the Commission to the Council and the European Parliament on the implementation of Council Regulation (EEC) No 259/93 of 1 February 1993 on the supervision and control of shipments of waste within, into and out of the European Community, and on the implementation of Regulation (EC) No 1013/2006 of 14 June 2006 on shipments of waste, COM(2012) 448 final, 8 August 2012.

Fajnzylber, P.; Lederman, D.; Loayzab, N. 2002. What causes violent crime? European Economic Review 6(7): 1323-1357. DOI: 10.1016/S0014-2921(01)00096-4

Faure, M. 2004. European environmental criminal law: do we really need it? European Energy and Environmental Law Review 18. ISSN: 0966-1646

Fise AssoAmbiente 2009. Gli impianti per il trattamento dei rifiuti in Italia. Available on the Internet: http://www.fondazionesvilupposostenibile.org/f/Documenti/Rapporto_Assoambiente_08_09.pdf

Fullerton, D.; Kinnaman T.C. 1995. Garbage, recycling, and illicit burning or dumping, Journal of Environmental Economics and Management 29: 78-91. DOI: 10.1006/jeem.1995.1032

Garoupa, N. 1997. The Theory of Optimal Law Enforcement, Journal of Economic Surveys 11(3): 267-295. DOI: 10.1111/14676419.00034

Giriūnas, L.; Mackevičius, J. 2014. Evaluation of frauds in public sector, Entrepreneurship and Sustainability Issues 1(3): 143-150. DOI: http://dx.doi.org/10.9770/jesi.2014.1.3(3)

Giriūnienè, G. 2013. Public sector`s subsidies to business - suitability valuation of labor market support measures, Entrepreneurship and Sustainability Issues 1(1): 37-44. DOI: http://dx.doi.org/10.9770/jesi.2013.1.1(4)

Gray, W.; Deily, M. 1996. Compliance and enforcement: air pollution regulation in the U.S. steel industry, Journal of Environmental Economics and Management 31: 96-111. DOI: 10.1006/jeem.1996.0034

Hamilton, J. T. 1996. Going by the (Informal) Book: The EPA's Use of Informal Rules in Enforcing Hazardous Waste Laws, Advances in the Study of Entrepreneurship, Innovation, and Economic Growth 7: 109-155.

Helland, E. 1998. The Revealed Preferences of State EPAs: Stringency, Enforcement, and Subsitution, Journal of Environmental Economics and Management 35: 242-261. DOI: 10.1006/jeem.1998.1028

Lankauskiené, T.; Tvaronavičienė, M. 2012. Security and sustainable development approaches and dimensions inn the globalization context, Journal of Security and Sustainability Issues 1(4): 287-297. DOI: http://dx.doi.org/10.9770/jssi.2012.1.4(5) 
Levitt, S. D. 1999. The Limited Role of Changing Age Structure in Explaining Aggregate Crime Rates, Criminology 37(3): $581-597$. DOI: $10.1111 / j .1745-9125.1999 . t b 00497 . x$

Mazzanti, M.; Montini, A. 2014. Waste management beyond the Italian north-south divide: spatial analyses of geographical, economic and institutional dimensions, in Kinnaman, T.C.; Takeuchi, K. (Eds.). Handbook on waste management. Edward Elgar.

Polinsky, A.M.; Shavell, S. 2000. The Economic Theory of Public Enforcement of Law, Journal of Economic Literature 38(1): 45-76. DOI: $10.1257 /$ jel.38.1.45

Račkauskas, M.; Liesionis, V. 2013. The relationship between government expenditure and public safety in Lithuania, Journal of Security and Sustainability Issues 3(2): 31-40. DOI: http://dx.doi.org/10.9770/jssi.2013.3.2(3)

Shinkuma, T. 2003. On the second-best policy of household's waste recycling, Environmental and Resource Economics 24: 77-95. DOI: 10.1023/A:1022842617469

Šileika, A.; Bekerytè, J. 2013. The theoretical issues of unemployment, poverty and crime coherence in the terms of sustainable development, Journal of Security and Sustainability Issues 2013 2(3): 59-70. DOI: http://dx.doi.org/10.9770/jssi.2013.2.3(5)

Stafford, S. 2002. The Effect of Punishment on Firm Compliance with Hazardous Waste Regulations, Journal of Environmental Economics and Management 44(2): 290-308. DOI: 10.1006/jeem.2001.1204

Stańczyk, J. 2011. European security and sustainability issues in the context of current international environment, Journal of Security and Sustainability Issues 1(2): 81-90. DOI: http://dx.doi.org/10.9770/jssi.2011.1.2(1)

Stigler, G. 1970. The optimum enforcement of laws, Journal of Political Economy 78: 526-36. DOI: 10.1086/259646

Sullivan, A.M. 1987. Policy options for toxics disposal: laissez-faire, subsidization, and enforcement, Journal of Environmental Economics and Management 14: 58-71. DOI: 10.1016/0095-0696(87)90006-4

Tunčikienè, Ž.; Drejeris, R. 2015. Entrepreneurship ecosystem: methodological approaches to functions' review of public sector institutions, Entrepreneurship and Sustainability Issues 2(3): 118-132. DOI: http://dx.doi.org/10.9770/jesi.2014.2.3(1)

Zahars, V.; Stivrenieks, M. 2015. Security implementation facets: peculiarities of execution of the sentence of imprisonment in respect of convicted minors, Journal of Security and Sustainability Issues 4(3): 221-231, DOI: http://dx.doi.org/10.9770/jssi.2015.4.3(3) 